\title{
IMPLIKASI KELUARNYA PERMEN KLHK P.68 TAHUN 2016 TENTANG BAKU MUTU LIMBAH DOMESTIK PADA PENEGAKAN HUKUM DI DKI JAKARTA DAN PEMILIHAN TEKNOLOGI PENGOLAHAN LIMBAH
}

\author{
Implications Permenklhk P.68 Of 2016 On Standards Of Quality Of Domestic Waste \\ to Law Enforcement and Selection Waste Processing Technology In Jakarta
}

Oleh :

Arie Herlambang dan Nusa Idaman said

Pusat Teknologi Lingkungan, BPPT

\begin{abstract}
Abstrak
Keberadaan peraturan untuk pengendalian pencemaran lingkungan telah berkembang dari waktu ke waktu sejalan dengan perubahan undang-undang lingkungan hidup. Di Indonesia sejak tahun 80'an sudah tiga kali mengalami perubahan dalam undang-undang lingkungan. Setiap perubahan undang-undang selalu diikuti oleh perubahan peraturan yang berada dibawahnya. Dari waktu ke waktu pencemaran lingkungan semakin parah dan membutuhkan peraturan yang lebih tegas dan implementatif. Peraturan yang terlampau ketat kadang tidak implementatif dan akhirnya banyak dilanggar karena tidak ada solusi jalan keluar yang tidak memberatkan para pihak. Limbah domestik adalah merupakan porsi limbah yang terbesar di perkotaan. Keberadaannya telah membuat lingkungan sungai, danau dan air tanah tercemar, akibat tidak dikelola dengan baik. Peraturan baku mutu limbah telah diperketat dari waktu ke waktu. Baku mutu air limbah adalah ukuran batas atau kadar unsur pencemar dan atau jumlah unsur pencemar yang ditenggang keberadaannya dalam air limbah yang akan dibuang atau dilepas ke dalam sumber air dari suatu usaha dan atau kegiatan. Keberadaan baku mutu lingkungan di Indonesia di atur oleh peraturan menteri lingkungan hidup. Keluarnya baku mutu limbah domestik nomor P.68/Menlhk/Setjen/Kum.1/8/2016 telah membawa konsekuensi pada perubahan penggunaan teknologi pengolahan limbah domestik, karena terjadi pengetatan pada beberapa parameter kunci yang selama ini masih dalam batas yang longgar.
\end{abstract}

Kata Kunci : Peraturan lingkungan, teknologi pengolahan limbah

\begin{abstract}
The existence of regulations to control environmental pollution has grown over time in line with changes in environmental legislation. In Indonesia since the ' 80 s has been three times experience changes in environmental legislation. Any change in the law is always followed by changes in regulations that are below it. From time to time, the environmental pollution is getting worse and require stricter regulations and implementation. Regulations are too strict sometimes not implementable and eventually are violated because there is no way out solution that does not burden the parties. Domestic waste is the largest portion of urban waste. Its existence has made the environment of rivers, lakes and ground water polluted, due to not properly managed. Regulation of waste quality standards have been tightened over time. Waste water quality standard is the limit or polluted substance or the amount of pollutant elements are tolerable in the waste water to be discharged or released into the water source from a business or activity. The existence of environmental quality standards in Indonesia are set by regulations of environment ministers. Discharge of domestic waste quality standards number P.68 / Menlhk / Secretariat / Kum.1 / 8/2016 has brought on changes in the use of domestic wastewater treatment technologies, as happened tightening in several key parameters, which is still within the limits loose.
\end{abstract}

Keywords : Environmental regulation, waste treatment technology 


\section{PENDAHULUAN}

Pencemaran dan perusakan lingkungan hidup di Provinsi DKI Jakarta sudah semakin meningkat yang mengarah kepada semakin memburuknya kondisi kualitas udara dan kualitas air di wilayah Provinsi DKI Jakarta.

Pencemaran dan perusakan lingkungan hidup tersebut salah satunya disebabkan oleh ketidak-taatan masyarakat dalam mematuhi ketentuan peraturan perundang-undangan di bidang lingkungan hidup. Oleh karena itu, untuk menghambat laju pencemaran dan perusakan lingkungan hidup khususnya di wilayah DKI Jakarta, diperlukan penegakan hukum lingkungan hidup secara terpadu. Berdasarkan pertimbangan tersebut di atas, Pemerintah DKI Jakarta telah menetapkan peraturan bersama tentang Penegakan Hukum Lingkungan Terpadu, yang ditandatangai bersama oleh Gubernur Provinsi DKI Jakarta, Kepala Kepolisian Daerah Metropolitan Jakarta Raya, Kepala Kejaksaan Tinggi Daerah Khusus Ibukota Jakarta dan Kepala Pusat Pengelolaan Lingkungan Hidup Regional Jawa.

\section{KETENTUAN UMUM}

Di dalam peraturan bersama tentang penegakan hukum lingkungan hidup terpadu di DKI Jakarta ada beberapa ketentuan umum antara lain :

- Daerah adalah Propinsi Daerah Khusus Ibukota Jakarta.

- Pemerintah Daerah adalah Gubernur dan Perangkat Daerah sebagai unsur penyelenggara Pemerintahan Daerah.

- Gubernur Propinsi Daerah Khusus Ibukota Jakarta yang selanjutnya disebut Gubernur adalah Gubernur Propinsi Daerah Khusus Ibukota Jakarta.

- Kepala Kepolisian Daerah Metropolitan Jakarta Raya yang selanjutnya disebut Kepala Kepolisian adalah Kepala Kepolisian Daerah Metropolitan Jakarta Raya.

- Kepala Kejaksaan Tinggi DKI Jakarta yang selanjutnya disebut Kepala Kejaksaan adalah Kepala Kejaksaan Tinggi DKI Jakarta.

- Satuan Tugas Penyelesaian Permasalahan Lingkungan Hidup atau disingkat STP2LH adalah tim yang dibentuk oleh Gubernur yang melibatkan instansi terkait di tingkat Propinsi yang bertugas membantu Gubernur dalam rangka pelaksanaan penyelesaian permasalahan lingkungan hidup;
- Satuan Tugas Penegakan Hukum Lingkungan atau disingkat STPHL adalah tim yang dibentuk oleh Gubernur yang merupakan gabungan dari komponen penegakan hukum yang melaksanakan Penegakan Hukum Lingkungan;

- Verifikasi adalah serangkaian kegiatan yang meliputi pemeriksaan kebenaran pengaduan, meneliti sumber pencemar dan atau perusakan lingkungan hidup, tingkat pencemaran dan atau perusakan lingkungan hidup, perkiraan jenis dan besar kerugian, lokasi terjadinya pencemaran dan atau perusakan lingkungan hidup, luas lokasi yang lerkena dampak, serta pihak yang bertanggung jawab atas terjadinya pencemaran dan/atau perusakan lingkungan hidup;

\section{MAKSUD DAN TUJUAN}

Maksud ditetapkannya Peraturan Bersama ini adalah untuk meningkatkan keterpaduan di antara Pemerintah Daerah, Kepolisian, Kejaksaan Tinggi, dan Pusat Pengelolaan Lingkungan Hidup Regional Jawa dalam pelaksanaan Penegakan Hukum Lingkungan Hidup di Propinsi DKI Jakarta.

Tujuan ditetapkan Peraturan Bersama tentang penegakan hukum lingkungan hidup terpadu ini adalah:

- Tercapainya Penegakan Hukum Lingkungan Hidup secara optimal melalui koordinasi dan kesamaan persepsi di antara Pemerintah Daerah, Kepolisian, Kejaksaan Tinggi, dan Pusat Pengelolaan Lingkungan Hidup Regional Jawa;

- Terwujudnya keterpaduan peningkatan kapasitas dan integritas dari Satuan Tugas Penyelesaian Permasalahan Lingkungan Hidup dan Satuan Tugas Penegakan Hukum Lingkungan di Propinsi DKI Jakarta;

- Terbentuknya sistem Penegakan Hukum Lingkungan Hidup Terpadu di Propinsi DKI Jakarta.

\section{RUANG LINGKUP}

Ruang lingkup Peraturan Bersama tentang penegakan hukum lingkungan hidup terpadu meliputi koordinasi :

- Penegakan hukum;

- Penyelesaian sengketa lingkungan hidup (melalui pengadilan dan di luar pengadilan);

- Sosialisasi dan penyuluhan; 
- Pertukaran data dan informasi; dan

- Pendidikan dan pelatihan.

\section{TIM PENEGAKAN HUKUM LINGKUNGAN HIDUP TERPADU}

Sebagai pelaksanaan dari Peraturan bersama tentang penegakan hukum lingkungan hidup dibentuk Tim Penegakan Hukum Lingkungan Hidup Terpadu Daerah.

Tim Penegakan Hukum Lingkungan Hidup Terpadu sebagaimana dimaksud terdiri dari Satuan Tugas Penyelesaian Permasalahan Lingkungan Hidup (STP2LH); Satuan Tugas Penegakan Hukum Lingkungan (STPHL); dan Sekretariat.

Pembentukan Tim Penegakan Hukum Lingkungan Hidup Terpadu sebagaimana dimaksud di atas ditetapkan dengan Keputusan Gubernur. Satuan Tugas Penyelesaian Permasalahan Lingkungan Hidup (STP2LH) terdiri dari :

- Pejabat Pengawas Lingkungan Hidup

- Kelompok Kerja Penelitian;

- Kelompok Kerja Teknis;

- Kelompok Kerja Hukum.

STP2LH mempunyai tugas antara lain yaitu :

- Verifikasi hasil pengawasan atau pengaduan yang selanjutnya memberikan rekomendasi penegakan hukum administrasi dan/atau penyelesaian sengketa lingkungan hidup dan/atau penegakan hukum pidana kepada instansi terkait dan/atau tim terkait yang tergabung dalam satuan tugas sesuai dengan kewenangan masing-masing;

- Penyusunan dan pengajuan gugatan ganti kerugian untuk penyelesaian sengketa lingkungan hidup melalui pengadilan atau menyelenggarakan penyelesaian sengketa lingkungan hidup di luar pengadilan.

Apabila telah terbentuk Lembaga Penyedia

Jasa Pelayanan Penyelesaian Sengketa Lingkungan Hidup di Luar Pengadilan. maka mediator pada lembaga tersebut merupakan bagian dari STP2LH.

Satuan Tugas Penegakan Hukum Lingkungan (STPHL) terdiri dari :

- PPNS Lingkungan Hidup;

- Penyidik POLRI;

- Jaksa/Penuntut Umum.

Satuan Tugas Penegakan Hukum Lingkungan (STPHL) mempunyai tugas melakukan penyelidikan (PULBAKET), penyidikan, penuntutan dan supervisi terhadap suatu kasus yang memenuhi kriteria telah terjadinya pencemaran dan/atau perusakan lingkungan (bukti permulaan yang cukup) atau adanya dugaan tindak pidana.

Mekanisme pelaksanaan tugas STPHL sebagaimana dimaksud di atas dilaksanakan sesuai dengan Peraturan perundang-undangan yang berlaku.

Dalam rangka pelaksanaan operasional penegakan hukum lingkungan hidup terpadu dibentuk/ditunjuk Badan Pengelolaan Lingkungan Hidup Daerah Propinsi DKI Jakarta sebagai Sekretariat, yang bertugas memperlancar pelaksanaan operasional tim penegakan hukum lingkungan hidup terpadu.

\subsection{Tata Cara Pengaduan}

Apabila diduga telah terjadi adanya pencemaran dan atau perusakan lingkungan hidup akibat suatu kegiatan, seseorang atau sekelompok orang dapat melaporkan baik lisan atau tertulis kepada instansi pemerintah terdekat misalnya Kelurahan, Kecamatan, Instansi yang bertanggungjawab di bidang pengelolaan lingkungan hidup, Kantor Kepolisian terdekat atau langsung kepada Satuan Tugas Penyelesaian Permasalahan Lingkungan Hidup (STP2LH) yang ada di BPLHD Propinsi DKI Jakarta.

Setiap orang yang mengadukan dugaan adanya pencemaran dan atau kerusakan lingkungan harus memberikan keterangan secara rinci beberapa hal yang meliputi :

- Identitas pengadu.

- Dugaan sumber pencemaran dan atau perusakan lingkungan.

- Waktu terjadinya pencemaran dan atau perusakan lingkungan.

- Akibat Yang terjadi.

- Keterangan lain.

Instansi peperintah yang menerima pengaduan adanya dugaan pencemaran dan atau perusakan lingkungan hidup mencatat semua keterangan yang telah disampaikan baik secara lisan ataupun tertulis.

Apabila dugaan pencemaran dan atau perusakan lingkungan hidup dilaporkan kepada Instansi pemerintah yang ada di wilayah Kabupaten/Kota, instansi yang bersangkutan wajib membuat laporan berjenjang kepada Bupati/walikota dan tembusanya kepada Gubernur melalui Satuan Tugas Penyelesaian Permasalahan Lingkungan Hidup (STP2LH) yang ada di BPLHD Propinsi DKI Jakarta.

Satuan Tugas Penyelesaian Permasalahan 
Lingkungan Hidup (STP2LH) yang menerima laporan pengaduan langsung atau tembusannselanjutnya melakukan verifikasi dan rapat koordinasi dengan anggota tim dan instansi terkait untuk menentukan tindakan penanganan lebih lanjut.

Setelah diadakan verifikasi dan rapat koordinasi STP2LH selanjutnya memberikan rekomendasi penegakan hukum administrasi dan/atau penyelesaian sengketa lingkungan hidup dan/atau penegakan hukum pidana kepada instansi terkait dan/atau tim terkait yang tergabung dalam satuan tugas Tim Penegakan Hukum Lingkungan Hidup terpadu.

\subsection{Penegakan Hukum Administrasi}

Sanksi Administrasi dijatuhkan oleh Gubernur/Bupati Walikota berdasarkan verifikasi hasil pengawasan atau pengaduan oleh Pejabat Pengawas Lingkungan Hidup yang tergabung dalam STP2LH.

Penanggung jawab usaha dan/atau kegiatan yang melakukan pelanggaran terhadap peraturan perundangundangan di bidang lingkungan hidup akan dikenakan sanksi administrasi sesuai peraturan perundang-undangan yang berlaku.

\section{PENYELESAIAN SENGKETA LINGKUNGAN}

Berdasarkan Peraturan Bersama tentang penegakan hukum lingkungan hidup terpadu, penyelesaian sengketa lingkungan hidup dapat dilakuan melalui pengadilan atau di luar pengadilan.

\subsection{Penyelesaian Sengketa Melalui Pengadilan}

- Penyelesaian sengketa melalui pengadilan dilaksanakan dengan mengajukan gugatan ganti kerugian dan/atau tuntutan melakukan tindakan tertentu ke pengadilan atas kerugian yang ditimbulkan bagi manusia dan lingkungan hidup akibat pencemaran dan/atau perusakan lingkungan hidup.

- Pengajuan gugatan ganti kerugian atau tuntutan untuk melakukan tindakan tertentu dilakukan oleh Pemerintah Pusat dan/atau Pemerintah Daerah dan dapat dikuasakan melalui Surat Kuasa Khusus.

- Penyusunan gugatan ganti kerugian dan/atau tuntutan sebagaimana dimaksud dalam ayat (2) dilakukan bersama STP2LH.

- Gugatan ganti kerugian disusun berdasarkan prinsip tanggungjawab mutlak atau strict liability sebagaimana dimaksud dalam Pasal 35 UndangUndang No. 23 Tahun 1997 tentang Pengelolaan Lingkungan Hidup.

\subsection{Penyelesaian Sengketa Di Luar Pengadilan}

- Penyelesaian sengketa di luar pengadilan dilakukan untuk memperoleh kesepakatan di antara para pihak yang berkepentingan mengenai bentuk dan besarnya ganti kerugian dan/atau tindakan pemulihan fungsi lingkungan hidup yang telah tercemar dan/atau rusak.

- Penyelenggaraan penyelesaian sengketa di luar pengadilan dilakukan oleh STP2LH.

- Mekanisme penyelesaian sengketa lingkungan hidup di luar pengadilan dilakukan sesuai peraturan perundang-undangan.

\section{PENEGAKAN HUKUM PIDANA}

\subsection{Penyidikan}

- Penyidikan terhadap tindak pidana lingkungan hidup dilakukan apabila telah adanya bukti permulaan yang cukup sesuai perundangundangan.

- Penyidikan dilakukan oleh Penyidik POLRI dan atau Pejabat Penyidik Pegawai Negeri Sipil yang tergabung dalam STPHL.

- Apabila dalam pelaksanaan penyidikan di lapangan mengalami hambatan, maka Penyidik POLRI wajib memberikan bantuan penyidikan dan pengamanan baik terhadap barang bukti maupun keamanan petugas, yang sedang melaksanakan tugas penyidikan di lapangan.

- Dalam hal Penyidik POLRI melakukan penyidikan, STPHL wajib memberikan bantuan yang diperlukan dalam rangka percepatan penyelesaian perkara tindak pidana lingkungan hidup.

- Bantuan penyidikan dan pengamanan Kepolisian diberikan kepada:

> Petugas STPHL yang akan dan sedang melaksanakan proses penyidikan. Olah TKP. termasuk kegiatan pencarian dan penyitaan barang bukti serta mencari tersangka maupun pengumpulan bahan keterangan dari para saksi-saksi.

Petugas STPHL yang akan dan sedang melaksanakan tugas penyidikan tindak pidana lingkungan hidup. 
Petugas STPHL yang akan dan sedang melaksanakan tindakan penyitaan barang maupun dan/atau membawa barang bukti dari tempat kejadian ke Tempat Penyimpanan atau Rumah Penyimpanan Benda Sitaan Negara (RUPBASAN).

- Dalam upaya menuntaskan proses penyidikan, maka Petugas STPHL wajib melaksanakan koordinasi dengan Penyidik POLRI sesuai peraturan perundang-undangan yang berlaku.

- Evaluasi Koordinasi antara Petugas STPHL dengan Penyidik POLRI dan Pihak Kejaksaan (Jaksa Penuntut Umum) dilaksanakan secara berkala minimal 3 (tiga) bulan sekali.

Sebelum berkas perkara Tahap Pertama diserahkan kepada Penuntut Umum. Penyidik Wajib melakukan Gelar Perkara.

\subsection{Penuntutan}

- Penuntutan tindak pidana lingkungan hidup dilakukan terhadap perkara hasil penyidikan yang telah dinyatakan memenuhi syarat formil dan materiil oleh Penuntut Umum dan telah diikuti dengan penyerahan tersangka serta barang bukti kepada Penuntut Umum.

- Penuntutan sebagaimana dimaksud dalam ayat (1) dilakukan oleh Jaksa Penuntut Umum baik yang tergabung di dalam maupun di luar STPHL sesuai peraturan perundang-undangan.

- Jaksa yang tergabung dalam STPHL dapat melakukan koordinasi penuntutan terhadap Jaksa Penuntut Umum di luar STPHL yang menangani perkara.

\section{PERTUKARAN DATA DAN INFORMASI}

Dalam rangka pelaksanaan operasional penegakan hukum lingkungan terpadu. Gubernur, Kepala Kepolisian, Kepala Kejaksaan Tinggi, dan Kepala Pusat Pengelolaan Lingkungan Hidup Regional Jawa bekerja sama untuk :

- Saling memberikan data dan informasi yang diperlukan yang berkaitan dengan perkembangan masalah-masalah pencemaran dan perusakan lingkungan;

- Pengembangan basis data dan informasi.

\section{SOSIALISASI DAN PENYULUHAN}

- Dalam rangka pengembangan sistem penaatan,
Gubernur, Kepala Kepolisian, Kepala Kejaksaaan Tinggi, dan Kepala Pusat Pengelolaan Lingkungan Hidup Regional Jawa bersepakat melakukan sosialisasi dan penyuluhan Penegakan Hukum Lingkungan Hidup.

- Pembentukan Tim Sosialisasi dan Penyuluhan Penegakan Hukum Lingkungan Hidup ditetapkan dengan Keputusan Gubernur.

- Sosialisasi dan penyuluhan sebagaimana dimaksud pada ayat (1) dikoordinasikan oleh Pusat Pengelolaan Lingkungan Hidup Regional Jawa atau dapat dilaksanakan oleh masingmasing instansi.

\section{PENDIDIKAN DAN PELATIHAN}

- Gubernur, Kepala Kepolisian, Kepala Kejaksaan Tinggi, dan Kepala Pusat Pengelolaan Lingkungan Hidup Regional Jawa bersepakat melakukan pengembangan sumber daya manusia melalui pendidikan dan pelatihan dalam rangka pembentukan sistem Penegakan Hukum Lingkungan Hidup Terpadu.

- Pendidikan dan pelatihan sebagaimana dimaksud pada ayat (1) dapat diselenggarakan oleh Kepala Pusat Pengelolaan Lingkungan Hidup Regional Jawa dan atau masing-masing instansi.

\section{PEMBIAYAAN}

Segala biaya sebagai akibat diterbitkannya Peraturan Bersama ini dibebankan pada Anggaran Pendapatan dan Belanja Negara, dan Anggaran Pendapatan dan Belanja Daerah Propinsi DKI Jakarta.

\section{KETENTUAN LAIN-LAIN}

- Segala bentuk yang mungkin timbul sebagai akibat diterbitkannya Peraturan Bersama ini akan diselesaikan secara bersama antara Gubernur, Kepala Kepolisian, Kepala Kejaksaan Tinggi, dan Kepala Pusat Pengelolaan Lingkungan Hidup Regional Jawa secara musyawarah dan mufakat.

- Dalam rangka pelaksanaan Peraturan Bersama ini, maka perlu disusun Rencana Kerja Penegakan Hukum Lingkungan Hidup Terpadu yang dikoordinasikan oleh Gubernur.

\section{MEKANISME PENEGAKAN HUKUM}


Peraturan bersama ini mulai berlaku pada tanggal diundangkan. Agar setiap orang mengetahuinya memerintahkan pengundangan Peraturan Bersama ini dengan penempatannya dalam berita Daerah Propinsi Daerah Khusus Ibukota Jakarta.
Mekanisme Penegakan Hukum Lingkungan Hidup terpadu di Propinsi DKI Jakarta dapat dilihat pada Gambar 1.

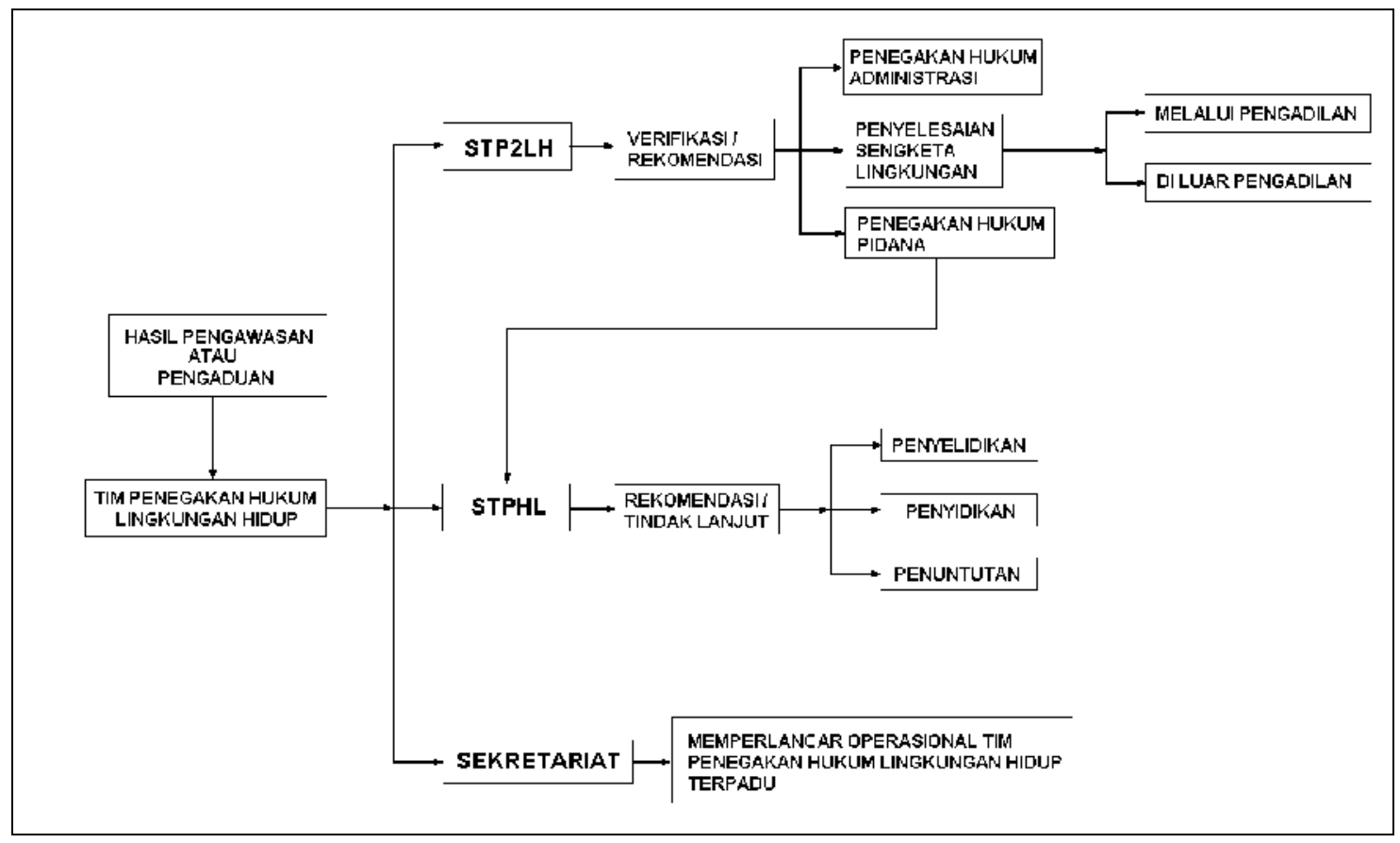

Gambar 1 : Mekanisme Penegakan Hukum Lingkungan Hidup Terpadu Di Propinsi DKI Jakarta.

\section{PERGUB 122 TAHUN 2004 TENTANG LIMBAH DOMESTIK}

Peraturan Gubernur Provinsi DKI Nomor 122 Tahun 2005 Tentang Pengelolaan Air Limbah Domestik dimaksudkan untuk mengurangi pencemaran badan air dari limbah domestik, yang pada kala itu cukup berpengaruh terhadap kualitas sungai yang melintasi kota Jakarta. Sebagai tindak lanjut operasional di lapangan adalah berubahnya baku mutu yang menjadi acuan pada saat monitoring lingkungan. Dalam 10 tahun terakhir nilai baku mutu limbah domestik yang menjadi acuan adalah $\mathrm{pH}, \mathrm{KmnO} 4$, TSS, Amoniak, Minyak dan lemak, Senyawa Biru Metilen, COD dan BOD. Hasil monitoring yang dilakukan selama ini parameter yang sering bermasalah adalah Amoniak, COD dan BOD, kondisi ini bisa dilihat dari hasil pelaporan IPLC, ternyata masih banyak perusahaan yang tidak memenuhi baku mutu lingkungan.
Tabel 1 : Baku Mutu Limbah Cair Domestik (Pergub Provinsi DKI Nomer 122 Tahun 2005).

\begin{tabular}{|l|c|c|c|}
\hline \multicolumn{1}{|c|}{ Parameter } & Satuan & $\begin{array}{c}\text { Individual } \\
\text { / Rumah } \\
\text { Tangga }\end{array}$ & Komunal \\
\hline $\mathrm{pH}$ & - & $6-9$ & $6-9$ \\
\hline $\mathrm{KmnO}_{4}$ & $\mathrm{mg} / \mathrm{L}$ & 85 & 85 \\
\hline $\mathrm{TSS}$ & $\mathrm{mg} / \mathrm{L}$ & 50 & 50 \\
\hline Amoniak & $\mathrm{mg} / \mathrm{L}$ & 10 & 10 \\
\hline Minyak \& Lemak & $\mathrm{mg} / \mathrm{L}$ & 10 & 20 \\
\hline $\begin{array}{l}\text { Senyawa Biru } \\
\text { Metilen }\end{array}$ & $\mathrm{mg} / \mathrm{L}$ & 2 & 2 \\
\hline COD & $\mathrm{mg} / \mathrm{L}$ & 100 & 80 \\
\hline BOD & $\mathrm{mg} / \mathrm{L}$ & 75 & 50 \\
\hline
\end{tabular}

Pemilihan teknologi pengolahan limbah menetukan kehandalan proses pengolahan. Terkait dengan teknologi pengolahan limbah domestik, yang sering dipakai adalah teknologi Lumpur Aktif, Rotating Biological Contactor (RBC), trikling filter, teknologi biofilter anaerob, teknologi biofilter aerob, dan 
teknologi biofilter kombinasi anaerob-aerob. Secara teknologi efisiensi proses pada teknologi-teknologi tersebut sudah cukup handal, berkisar 85 sd 95\%. Pencapaian target olahan BOD 75 mg/l dan COD 100 $\mathrm{mg} / \mathrm{l}$ pada limbah domestic sebetulnya tidak terlampau sulit, karena pada umumnya limbah domestik kualitas air bakunya berkisar BOD 250 - 350 mg/liter. Namun pada saat operasional sering dijumpai pompa blower mati atau rusak atau tidak diopersionalnya, sehingga amoniaknya melonjak di atas $10 \mathrm{mg} / \mathrm{l}$.

\section{PERMENLHK RI NOMER P.68 Tahun 2016 TENTANG LIMBAH DOMESTIK}

Menimbang pelaksanakan ketentuan Pasal 20 ayat (2) huruf b Undang-undang Nomor 32 Tahun 2009 tentang Perlindungan dan Pengelolaan Lingkungan Hidup, Menteri mengatur ketentuan mengenai baku mutu air limbah; bahwa air limbah domestik yang dihasilkan dari skala rumah tangga dan usaha dan/atau kegiatan berpotensi mencemari lingkungan, sehingga perlu dilakukan pengolahan air limbah sebelum dibuang ke media lingkungan; erdasarkan ketentuan sebagaimana dimaksud dalam huruf a dan huruf $b$, perlu menetapkan Peraturan Menteri Lingkungan Hidup dan Kehutanan tentang Baku Mutu Air Limbah Domestik;

Mengingat Undang-Undang Nomor 32 Tahun 2009 tentang Perlindungan dan Pengelolaan Lingkungan Hidup (Lembaran Negara Republik Indonesia Tahun 2009 Nomor 140, Tambahan Lembaran Negara Republik Indonesia Nomor 5059); Peraturan Pemerintah Nomor 82 Tahun 2001 tentang Pengelolaan Kualitas Air dan Pengendalian Pencemaran Air (Lembaran Negara Republik Indonesia Tahun 2001 Nomor 153, Tambahan Lembaran Negara Republik Indonesia Nomor 4161);

Peraturan Presiden Nomor 16 Tahun 2015 tentang Kementerian Lingkungan Hidup dan Kehutanan (Lembaran Negara Republik Indonesia Tahun 2015 Nomor 17); Peraturan Menteri Lingkungan Hidup dan Kehutanan Nomor P.18/ MenLHK-II/2015 tentang Organisasi dan Tata Kerja Kementerian Lingkungan Hidup dan Kehutanan (Berita Negara Republik Indonesia Tahun 2015 Nomor 713);

Dengan Keluarnya Permenlhk RI Nomer P.68 Tahun 2016 Tentang Limbah Domestik, ada perubahan mendasar, yaitu terjadi pengetatan baku mutu dari beberapa parameter, antara lain : BOD, TSS, Minyak dan lemak, dan total coliform.

Tabel 2 : Baku Mutu Limbah Domestic P. 68 Tahun 2016.

\begin{tabular}{|l|c|c|}
\hline \multicolumn{1}{|c|}{ Parameter } & Satuan & $\begin{array}{c}\text { Kadar } \\
\text { Maksimum }\end{array}$ \\
\hline $\mathrm{pH}$ & - & $6-9$ \\
\hline $\mathrm{BOD}$ & $\mathrm{mg} / \mathrm{L}$ & 30 \\
\hline $\mathrm{COD}$ & $\mathrm{mg} / \mathrm{L}$ & 100 \\
\hline TSS & $\mathrm{mg} / \mathrm{L}$ & 30 \\
\hline Minyak \& Lemak & $\mathrm{mg} / \mathrm{L}$ & 5 \\
\hline Amoniak & $\mathrm{mg} / \mathrm{L}$ & 10 \\
\hline Total Coliform & Jumlah/100 $\mathrm{mL}$ & 3000 \\
\hline Debit & L/orang/hari & 100 \\
\hline
\end{tabular}

Pada kondisi saat ini pencapaian hasil olahan limbah domestic dengan BOD $30 \mathrm{mg} /$ liter sangat mungkin bisa dicapai dengan kondisi awal 250 - 350 $\mathrm{mg} /$ liter, demikian juga dengan TSS $30 \mathrm{mg} /$ liter, namun persyaratan baku mutu untuk total koliform menjadi masalah karena implikasinya pada setiap sistem IPAL harus dipasang system disinfektak untuk menurunkan jumlah effluent dari coliformnya. Kebutuhan kaporit untuk proses disinfektan akan meningkat karena masih ada amonianya, sehingga kebutuhan kaporit untuk proses disinfektan menjadi meningkat. Untuk kotakotab besar seperti Jakarta, Semarang, Bandung, Surabaya kaporit tidak masalah, namun akan menjadi jika dikota-kota kecil dan terpencil, akibatnya banyak system IPAL yang akan tidak dapat memenuhi baku mutu terutama untuk parameter total coliform, terutama pada system sanitasi yang berbasis masyarakat (sanimas-sanimas).

\section{KESIMPULAN}

- Penegakan hukum lingkungan, khususnya pada industry tidak bisa serta merta diterapkan, karena menyangkut proses produksi ;

- Banyaknya pelanggaran terhadap baku mutu lingkungan diakibatkan kesalahan dalam pemilihan teknologi ;

- Kurangnya pengetahuan operator llimbah menyebabkan teknologi IPAL yang ada dijalankan tidak optimal ;

- Baku mutu limbah domestic DKI Jakarta Nomer 122 Tahun 2005, selama ini menjadi acuan nasional dan ternyara masih banyak IPAL yang belum memenuhi baku mutu ;

- Untuk kasus DKI Jakarta baku mutu yang sering terlampaui adalah amoniak dan Total Coliform ;

- Parameter amoniak menunjukkan sistem yang digunakan harus dilengkapi dengan system aerobic ; 
- Untuk menurunkan Total Coliform system IPAL harus dilengkapi dengan system disinfektan.

- Untuk implentasi secara nasional P. 68 Tahun 2016 membawa konsekuensi naiknya biaya operasional IPAL dan diperlukan perbaikan system perdagangan kaporit dalam skala nasional.

- Sistem sanimas yang berada di pedesaan akan terancam tidak memenuhi baku mutu dan diperlukan perubahan pada teknologi IPAL-nya.

\section{DAFTAR PUSTAKA}

- The Study OnUrban Drainage And Waste Water Disposal Project In The City Of Jakarta", , JICA, December 1990.

- Keputusan Gubernur Kepala Daerah Khusus Ibukota Jakarta Nomor 582 Tahun 1995 Tentang Penetapan Peruntukan Dan Baku Mutu Air Sungai atau Badan Air Serta Baku Limbah Cair Di Wilayah Daerah Khusus Ibukota Jakarta

- Keputusan Gubernur Propinsi DKI Jakarta No. 2863 tentang Jenis Rencana Usaha dan/atau Kegiatan Yang Wajib Dilengkapi Dengan AMDAL.

- Keputusan Gubernur Propinsi DKI Jakarta nomor 1775/2007 Tentang Pembentukan Tim Penegakan Hukum Lingkungan Hidup Terpadu Propinsi Daerah Khusus Ibukota Jakarta.

- Keputusan Gubernur Propinsi DKI Jakarta Nomor 30/1999 tentang Ijin Pembuangan Limbah cair (IPLC).

- Keputusan Gubernur Propinsi DKI Jakarta Nomor 57 Tahun 2003 tentang Petunjuk Pelaksanaan Izin Pembuangan Limbah Cair di Propinsi Daerah Khusus Ibukota Jakarta.

- Keputusan Gubernur Propinsi DKI Jakarta Nomor 57/2003 tentang Petunjuk Pelaksanaan Izin Pembuangan Limbah Cair di Propinsi Daerah Khusus Ibukota Jakarta.
- Keputusan Menteri Negara Lingkungan Hidup Republik Indonesia Nomor : Kep-52/Menlh/10/1995 Tentang Baku Mutu Limbah Cair Bagi Kegiatan Hotel.

- Peraturan Gubernur Provinsi DKI Jakarta Nomor 122 Tahun 2005 Tentang Pengelolaan Air Limbah Domestik Di Provinsi DKI Jakarta.

- Peraturan Bersama Gubernur Propinsi Daerah Khusus Ibukota Jakarta, Kepala Kepolisian Daerah Metropolitan Jakarta Raya, Kepala Kejaksaan Tinggi Daerah Khusus Ibukota Jakarta, DanKepala Pusat Pengelolaan L1ngkungan Hidup Regional Jawa Nomor 101 TAHUN 2007 ; Nomor 13/5576/VII/2007/Datro; Nomor 133845/0.1/GP/06/2007; Nomor Kep-41B/PPLHReg.4/06/2007; Tentang Penegakan Hukum L1ngkungan Hidup Terpadu.

- Peraturan Gubernur Provinsi Daerah Khusus Ibukota Jakarta Nomor 68 Tahun 2005 Tentang Perubahan Keputusan Gubernur Provinsi Daerah Khusus Ibukota Jakarta Nomor 115 Tahun 2001 Tentang Pembuatan Sumur Resapan

- Peraturan Pemerintah Republik Indonesia Nomor 82 Tahun 2001 Tentang Pengelolaan Kualitas Air Dan Pengendalian Pencemaran Air.

- Undang-Undang Republik Indonesia Nomor 23 Tahun 1997 Tentang Pengelolaan Lingkungan Hidup

- Pergub 122 Tahun 2004 Tentang Limbah Domestik

- Permenlhk Ri Nomer P.68 Tahun 2016 Tentang Limbah Domestik 